\title{
The Use of Cooperative Round Robin Discussion Model to Improve Students' Holistic Ability in TEFL Class
}

\author{
Slamet Asari ${ }^{1}$, Ulfatul Ma'rifah ${ }^{1} \&$ Yudhi Arifani ${ }^{1}$ \\ ${ }^{1}$ English Department University of Muhammadiyah, Gresik, Indonesia \\ Correspondence: Slamet Asari, English Department University of Muhammadiyah Gresik, Jl. Sumatera 101 \\ GKB Randuagung, Gresik, Indonesia. Tel: 62-813-3065-6400. E-mail: asarififi70@yahoo.com
}

Received: April 12, 2016

doi:10.5539/ies.v10n2p139
Accepted: September 2, $2016 \quad$ Online Published: January 30, 2017

URL: http://dx.doi.org/10.5539/ies.v10n2p139

\begin{abstract}
This classroom action research is carried out within two cycles to breed a strategy on how a Round Robin Discussion Learning Model enhance students' critical thinking, presentation skills, confidence, and independent learning in Teaching English as a Foreign Language (TEFL) class. Pop-up quiz, teacher made-tests, classroom participation sheet, observation sheet, and rubric are utilized in the study. In addition, the collected data are then scrutinized via quantitative and qualitative doctrine. Quantitative analysis is pertained to gauge students' critical comprehension on TEFL issues through test, quiz, and worksheet. Meanwhile, for the qualitative analysis, constant comparative method is executed to enlighten parallel variable to depict students' presentation skills, confidence, and independent learning. The result of the study uncovers that guided question and answer session within and without the group foster students' higher order thinking skills and the results of the tests, pop-up quizzes indicates significant upgrading from $66 \%$ into $82 \%$. Next, round presentation in and out group activity also cultivates students' presentation skills as well as confidence and independent learning from $65 \%$ to $85 \%$, $67 \%$ into $77 \%$, and from $65 \%$ to $93 \%$. Round Robin discussion model operates well if it is supported with fixed and detailed roles of both students and teacher so that equal interactive practice is well established.
\end{abstract}

Keywords: holistic ability, round robin model, TEFL

\section{Introduction}

TEFL course falls on one of subjects under the domain of English teaching skills. The course is offered for the fourth semester students of English department. As a prerequisite subject, all students have to complete this class before they dive into the real classroom teaching practices at senior high school as internship program at the sixth semester. This course encourages or equips students with the principle of teaching English as a foreign language. It also covers and elaborates EFL teachers professional development, the theories of teaching English skills (listening, speaking, reading, and writing) as well as the teaching of English components (grammar, vocabulary, pronunciation), the development of teaching media and classroom management (Brown, 2007; Harmer, 2001) and the principle of assessing EFL Learners (Gebhard, 1996, pp. 49-89, pp. 143-221; Hedge \& Tricia, 2000, pp. 375-400).

During teaching learning process problem identification is issued in order to define relevant issues on the EFL classroom teaching and learning. During problem identification phase, teaching activities on TEFL class was implemented via students centered learning model. Group presentation, discussion were done in every meeting and pop-up quiz after four meetings. The teaching focus mainly relies on TEFL theories comprehension through group presentation where each group present different topics in each meeting. In this case, the teacher acts as facilitator in every discussion to manage the flow of the activities. The teacher also provides feedback toward the essence of the discussion and presentation as well as explaining and underlining the topic discussed in the classroom. This baseline is in favor with Ngaraju et al. (2013) which claimed that the teacher-centered learning model does not afford adequate chance for the students to communicate optimally in the classroom. Meanwhile, individual presentation skill was not deemed optimally to see individual progress but it highlights merely knowledge-based paradigm. Other important elements in the presentation and discussion such as presentation skill, confidence, and independent presentation are not well addressed yet in the teaching and learning process.

From the above portrayal; three main issues can be drawn. The first issue is related to discussion process. Although the discussion process is relatively communicative where every student can share their idea in turn but 
it seems that, every student has limited time to share his or her idea. One of the possible problems is that each group discussion discusses different topic in every meeting. So the chance to speak up and share ideas for individual student is relatively harder and very time consuming. Even for the less confident students, presentation activity is little bit scary for them as they are rarely involved and trained in the smaller group presentation step by step before they face the real classroom presentation. Secondly, cooperative process between and among individual interaction is not well addressed as well especially related to students' autonomous learning. Although the teaching and learning activity employs cooperative model but learning remains individual. Consequently, individual learning autonomy should be overviewed more optimally. Thirdly, assessment process also befalls another crucial point. It should be able to address every single aspect of learning. As a result, the need of relevant assessment rubric is another vital point not only looking at the students' cognitive domain but it should also be able to assess students' affective aspects.

Considering the above arguments, it is necessary to reformulate the teaching and learning procedures in order to heighten students' holistic ability. Blanton (1992) suggested that holistic teaching should be able to blend and facilitate integrative teaching skills and components into more meaningful ways to foster all learners' potential in all domains through effective teaching and learning.

This study aims at addressing three main issues namely, how to improve students' holistic ability in TEFL class covering students' confidence, independent learning, and critical thinking skill using Round Robin discussion model. Consequently, it is expected that this study will provide opportunity for students to have self-confidence and to build their critical thinking. In addition to these significances, through the process of teaching and learning using Round Robin discussion students' English exposure will be developing and at the same time students' mistakes are easily determined when pronouncing particular words during presentation as what Round Robin discussion is meant to be.

\section{Method}

A Collaborative Classroom Action Research (CAR) design is implemented within two cycles with eight meetings in the study. Cooperative teaching strategy using Round Robin discussion model is executed to generate a strategy on fostering students' critical thinking, confidence, presentation skills and learning independence for the fourth semester students of English Department University of Muhammadiyah Gresik who enrolled TEFL course with 10 male and 15 females participated in the study. The Classroom Action Research procedures are developed exploiting Kemmis and McTaggart (1992), Sukmadinata (2006), Kunandar (2008). Three main steps, namely planning phase, implementing and observing phases, and reflecting phase are applied in a rigid route. The step of CAR is shown in the following diagram.

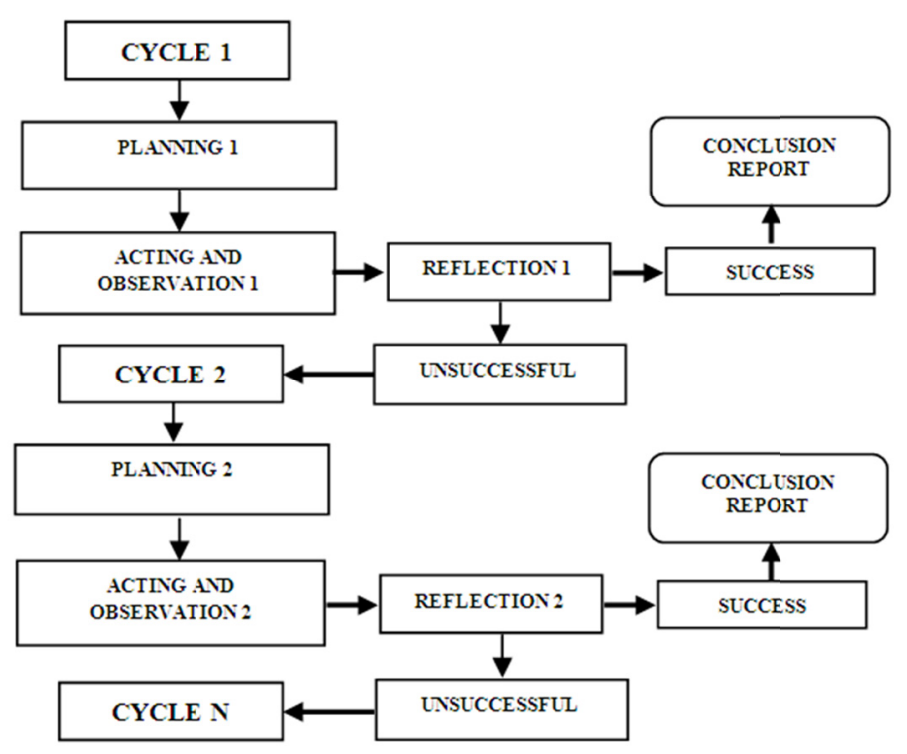

Diagram 1. CAR Cycles (Kemmis \& McTaggart, 1992) 
The qualitative data on the commonalities of how Round Robin strategy operates significantly in the classroom teaching and learning are collected via eight times classroom observations by the team teaching (three lecturers) as observers of TEFL course in every classroom teaching activity. The data are then scripted and explained qualitatively to yield the most common strategies. Next, students' presentation skills, confidence, and individual learning are obtained from presentation skills rubric and scoring guide. Pop-up quiz, questionnaire are also implemented to collect the data on students' higher order thinking skills through quiz and students' autonomous learning and confidence are obtained simultaneously via questionnaire and observation checklist as well.

The collected data are then analyzed through both quantitatively and qualitatively. Qualitative data analysis is interpreted to explain the emerging commonalities implementation of the planned strategy. On the other hand, the quantitative technique is implemented to analyze the result of pop-up quiz and questionnaire. Finally, triangulation is done in reflecting stage by comparing the observation results, questionnaire, and rubric with the criteria of success of the study.

The indicators of success in this study are overviewed into the following statements. Firstly, students' ability to think critically is drawn from several dimensions, namely: a) the ability to hand over critical comprehension questions, b) the ability to respond to critical questions from a teacher and/ or student, and c) ability to present a logical argument. Critical thinking indicator is achieved if the students' minimal average score perform $(71 \leq \mathrm{PP}$ $\leq 100$ ) with the following range:

$$
\begin{array}{ll}
\mathrm{A}=80 \leq \mathrm{PP} \leq 100 & : \text { Very Critical } \\
\mathrm{B}=66 \leq \mathrm{PP} \leq 79 & : \text { Critical } \\
\mathrm{C}=56 \leq \mathrm{PP} \leq 65 & : \text { Less Critical } \\
\mathrm{D}=\quad \leq \mathrm{PP} \leq 55 & : \text { Not Critical }
\end{array}
$$

Secondly, to depict students presentation skills, an observation rubric and scoring guide is applied. It covers four dimensions, namely: a) Performance and Strategy, b) Material Organization, c) Presentation Fluency, and d) Language Use. Presentation skills indicator is achieved if the students' minimal average score perform $(71 \leq \mathrm{PP}$ $\leq 100$ ) with the following range:

$$
\begin{aligned}
& 80 \leq \mathrm{PP} \leq 100 \quad \text { : Very Satisfactory } \\
& 66 \leq \mathrm{PP} \leq 79 \quad \text { : Satisfactory } \\
& 56 \leq \mathrm{PP} \leq 65 \quad \text { : Less Satisfactory } \\
& \leq \mathrm{PP} \leq 55 \quad: \text { Not Satisfactory }
\end{aligned}
$$

The assessment of students' presentation ability is calculated in each dimension of presentation skill above. Then, the average score is obtained and converged into the previous determined range.

Thirdly, the description of students' confidence is measured through using confidence rubric and questionnaire. The content of the rubric of confidence comprises three dimensions, namely: a) present his/her ideas in natural way, b) communicate naturally with others, and c) confronting ideas. Students' confidence indicator is achieved if the students' minimal average score perform $(71 \leq \mathrm{PP} \leq 100)$ with the following range:

$$
\begin{aligned}
80 & \leq \mathrm{PP} \leq 100 \quad: \text { Very Confident } \\
66 & \leq \mathrm{PP} \leq 79: \text { Confident } \\
56 & \leq \mathrm{PP} \leq 65: \text { Less Confident } \\
& \leq \mathrm{PP} \leq 55: \text { Not Confident }
\end{aligned}
$$

Fourthly, the portrayal of students' independent learning is measured via independent learning rubric and questionnaire. The focus of independent learning variables consists of three elements, namely: a) doing students' worksheet independently, b) presentation with his/or her own words and c) executing his/her own learning style. Students' autonomous or independent learning indicator is achieved if the students' minimal average score perform $(71 \leq \mathrm{PP} \leq 100)$ with the following range:

$$
\begin{array}{ll}
80 \leq \mathrm{PP} \leq 100 & : \text { Very Independent } \\
71 \leq \mathrm{PP} \leq 79 & : \text { Independent } \\
66 \leq \mathrm{PP} \leq 70 & : \text { Less Independent } \\
61 \leq \mathrm{PP} \leq 65 & : \text { Not Independent }
\end{array}
$$




\section{Result and Discussion}

\subsection{Students' Critical Thinking Ability}

Assessment process in final scoring on the TEFL course is projected on the objective of teaching and learning process that is specially distributed into quizzes after the students' presentation to measure students' comprehension toward the topic learned in every meeting. Quiz and test scores categorized into the level of higher order comprehension. Burn, Ross and Ross (1996:255) classified four types of comprehensions namely literal, interpretive, critical and creative comprehension. From the three types of comprehension, critical and creative comprehensions are considered more significantly contributive to foster students' critical comprehension than literal comprehension itself.

The topics discussed in the first and second cycle consists of six topics, namely: a) Developing EFL/ESL Teaching Media, b) Classroom Management, c) Teaching Listening, d) Teaching Speaking, e) Teaching Reading, f) Teaching Writing, and g) Assessing EFL/ESL Teaching. The goal of the teaching is to equip the students with the principles of teaching English as a Foreign Language (EFL) before they implement the real teaching practice at schools with the real students in the real teaching and learning context at EFL setting in the following semester The course weight is 3 credits within 150 minutes in each meeting to accomplish two up to three basic competences. One of cooperative teaching strategies is implemented under the Round Robin Discussion strategy where the class is divided into groups with four to five students in each group so can they can implement within group presentation more effectively before they conduct classroom presentation. Every group also discussed the same topic so that in one meeting all groups also talk, discuss and present similar topic. The main teaching started with internal group presentation, where each member of the group presented the topic using their own language. They are not allowed to follow the language from the book because another member in the group will monitor the language use, provide question from each internal group presentation. It lasts around eight meetings for the two cycles with some improvement on the strategy as part of concept generating with two additional meetings for micro-teaching practice. This activity is called concept generating so that all students will have similar perception on the concept they are learning. On question and answer sessions, Wh-question types were addressed to train students' critical comprehension emerged in the classroom. The following are some example of the questions emerged in the classroom teaching: a) "Did you think that English teachers at elementary school in Indonesia develop their professionalism well?", b) "How should we teach English grammar to young learners?", c) "How did we correct students' language errors effectively?", and d) "When should we correct students' language errors?".

Quiz and test were administered step by step. The quiz was implemented every meeting through students' worksheet and pop-up quiz done after finishing the implementation of Round Robin discussion method on the two discussed topics had been learned. Meanwhile, test was administered at the end of every four meetings or after each cycle was completed. From the results of the quiz in every meeting, classroom observation and tests, students' critical thinking skills, it is drawn that on the cycle I around $66 \%$ from 25 students achieved on the level of beginning of critical thinking on the first dimension of critical comprehension, namely the ability to hand over critical comprehension questions. The initial transition may possibly cause of this situation since as usually they were training teacher-centered model where the teacher has a role in explaining the concepts of TEFL so that they used to listen and rely from teacher's explanation. In addition, the ability to respond critical questions from a teacher and or student showed that approximately $67 \%$ and the ability to present a logical argument showed about $65 \%$ on the level of initial stages of criteria of success.

The above phenomena came up as in the implementation of Round Robin Discussion most of the students were still hesitate to deliver their questions within their group. The worse thing happened in the classroom discussion where only couples of students were active the bigger classroom presentation context. It could be generated a proposition that If the students did not equally participated in the small round robin discussion group so it can be projected that the bigger classroom discussion will only dominated by smarter students. Consequently, time limit, equal roles of each member of small group should be maintained very strictly. Psychologically according to Aydin, et al (2008) and Chan et al (2000) claimed that one of the influential factors in EFL teaching is anxiety. It is possibly caused by the inability to communicate in English fluently in the classroom. The common emerging questions from the classroom discussion both within small group and among group round robin discussion were in the form of literal questions. The following are the examples of literal questions: a) In your explanation, you did not mention the definition of classroom management, so what is classroom management?", b) "What is the example of direct and indirect error correction!", c) What is the differences between TEFL/TESL?" and d) what did you mean with teaching integrated skill?". These literal questions often come up during the discussion. Cosequently, it affects students' ability in building up their idea toward the critical aspects on the essential 
element of the topic being discussed. It is little bit far from teacher's expectation. Commenting on this point, Arifani (2016) reported that the quality of students' questions when doing discussion such as in team-based discovery learning which may be considered as cooperative learning strategy influence students' thinkhing skills. Further, students' thinking skill should be guided and trained step by step through the coopeartive learning to enhance critical concept attainment

Several improvements are prepared and implemented. Improvements are generated from the three observers as part of the implementation of lesson study grant from government. The improvements stressed on three elements. First, each student is assigned to summarize by paraphrasing the topic they are learning in a piece of paper a week before classroom begins to avoid so many direct quotations. Second, the student is assigned to prepare at least five wh-questions type and alternative answers from the prepared questions to train them questioning and answering skills. Third, it is created an equal chance and role for each student in the classroom in every single classroom activity to avoid smarter and more active students' dominance occurred. It also includes the limitation of within group presentation time, discussion and question time limit, number of question delivered by equal student, and number of students who answer the question. All strategies are implemented in the second cycle so that the teacher functions the role as regulator, facilitator and assessor to monitor whether all students have similar chance or not to yield an effective and meaningful interaction from the classroom teaching and learning. All the three observers also monitored the implementation of the improved strategy. After some strategies of improvement on the implementation of a round robin discussion model, the students' score of critical comprehension skills positively increased with approximately $22 \%$ for the dimension of the ability to hand over critical comprehension questions from $67 \%$ into $89 \%$. The second dimension is the ability to respond critical questions from a teacher and or student. It showed positive improvement as well with approximately $24 \%$ from $65 \%$ into $79 \%$. The third dimension of critical thinking skill is the ability to present a logical argument significantly improved around $13 \%$ from $65 \%$ into $78 \%$. Overall critical thinking skills, it showed significant improvement with around $16 \%$ from $66 \%$ in the first cycle, into $82 \%$ in the second cycle. The overall improvement result is displayed in the following Table 1.

Table 1. Percentage of students' critical thinking skill score (Cycle I \& II)

\begin{tabular}{llcc}
\hline \multirow{2}{*}{ Variable } & Dimension & $\begin{array}{c}\text { Percentage } \\
\text { Cycle I }\end{array}$ & $\begin{array}{c}\text { Percentage } \\
\text { Cycle II }\end{array}$ \\
\hline Critical Thinking Skill & Ability to hand over critical comprehension questions & 67 & 89 \\
& Ability to respond critical questions from a teacher and or student, and c & 65 & 79 \\
& Ability to present a logical argument. & 65 & 78 \\
Average & & 66 & 82 \\
\hline
\end{tabular}

Table 2. Percentage of students' presentation skill (Cycle I \& II)

\begin{tabular}{llcc}
\hline Variable & Dimension & $\begin{array}{c}\text { Percentage } \\
\text { Cycle I }\end{array}$ & $\begin{array}{c}\text { Percentage } \\
\text { Cycle II }\end{array}$ \\
\hline \multirow{2}{*}{ Students' Presentation Skill } & Performance and Strategy & 67 & 87 \\
& Material Organization & 61 & 87 \\
& Presentation Fluency & 65 & 89 \\
& Language Use & 68 & 78 \\
Average & & 65 & 85 \\
\hline
\end{tabular}

Table 3. Percentage students' confidence (Cycle I \& II)

\begin{tabular}{llcc}
\hline Variable & Dimension & $\begin{array}{c}\text { Percentage } \\
\text { Cycle I }\end{array}$ & $\begin{array}{c}\text { Percentage } \\
\text { Cycle II }\end{array}$ \\
\hline Students' Confidence & Present his/her ideas in natural way & 69 & 78 \\
& Communicate naturally with others & 66 & 78 \\
& Confronting ideas & 65 & 75 \\
& Average & 67 & 77 \\
\hline
\end{tabular}


Table 4. Percentage students' independent learning (Cycle I \& II)

\begin{tabular}{llcc}
\hline \multirow{2}{*}{ Variable } & Dimension & $\begin{array}{c}\text { Percentage } \\
\text { Cycle I }\end{array}$ & $\begin{array}{c}\text { Percentage } \\
\text { Cycle II }\end{array}$ \\
\hline \multirow{2}{*}{ Students' Independent Learning } & Doing students' worksheet/tasks independently & 67 & 97 \\
& & 62 & 94 \\
& Presentation with his/or her own words & 65 & 87 \\
& Executing his/her own learning style & 65 & 93 \\
\cline { 2 - 4 } & Average & & \\
\hline
\end{tabular}

\subsection{Students'Presentation Skill}

The activity of students' presentation is implemented through small group discussion using round robin discussion model where each student in each group consisting four to five members in one group. Each student in a group is assigned to present in turn one by one with similar topic to discuss and understand. Question and answer, and discussion is also conducted within the group. The duration to finish the in group discussion takes twenty five minutes. After finishing the first round, it went on with out or among group presentation and discussion. The objective of the in group discussion is to train students with the ability of presentation skill and topic mastery on how well they achieved the comprehension of topic being discussed as well as how good or skillful the students are doing a presentation in front of the classroom. These activities were done both on the first and the second cycle with the total of meeting is eight meetings. The result of students' presentation skill or ability is assessed by using presentation rubric that covers four dimensions. They are performance strategy, material organization, presentation fluency and language use. On the cycle 1, the result of assessment showed students' ability in conducting presentation is still on the category of less satisfactory level with the average score reached approximately $65 \%$. It took place as in the first cycle most of the students restate the content of the topic from the books in the presentation without doing paraphrase before. Only several students that are categorized into higher achiever students tend to dominate the classroom discussion within and without group presentation.

The lowest achievement is on the dimension of organization of material presentation with the assessment score falls around $61 \%$. It happened because most of the students like to write the content of the material precisely from their books on their power point with less elaboration. They also had a problem in elaborating the main key words in their slides. Moreover, content of the lines displayed in the slide of power point look too many which is more than 15 lines with longer complex sentences or paragraph. Consequently, it influences their presentation performance as they cannot freely express their idea and they tended to read their slide. On the other hand, presentation fluency is not as low as the previous dimension. It falls around $67 \%$ and it categorized into initial satisfactory level of presentation skill rubric. The third and the fourth dimensions of presentation fluency and language use perform approximately $65 \%$ and $68 \%$. One of the influential factors is student's confidence is not built yet as this activity becomes the first for the students and they are not trained their presentation skill step by step.

As an improvement step, on the following cycle several improvements are made. First, the improvement emphasized on students' ability in paraphrasing and using their own language before presenting their topic within the group and among the groups. In this case, the students are assigned to prepare their summary using their own words as well as their questions and possible answers. Second, when they prepare their presentation slide, they have to write down the key words into more concise organization not more than ten lines in each slide using their own sentence. It is meant to avoid reading the content lines shown in the slide in their presentation. Fourth, the teacher made strict rules for the students in conducting round robin discussion method. Each student has to present within five minutes in their group. Another member of the group prepare critical question to deliver to the presenter in turn one by one. Smarter students are scattered into different group so they can disseminate their take and give process within the group presentation and among the group presentation. Based on the above improvement, in the cycle two, students' presentation skill significantly improves from $65 \%$ into $85 \%$. It increases $20 \%$. The increase of students' performance and presentation strategy reaches $87 \%$ from previously $67 \%$. Material organization dimension achieves approximately $26 \%$ from 61 into 87 . Next, from the dimension of presentation fluency, it increases from $65 \%$ into $89 \%$. For the dimension of language use, it also improves from $68 \%$ into $78 \%$ and it has $20 \%$ increases than previously. The improvement strategy is in line with Delli-Carpini (2006), he argued that structured assignments toward the member of each group discussion using Round Robin discussion will optimize the teaching and learning process. It also fosters students' responsibility in 
the discussion process.

\subsection{Students' Confidence}

Students' confidence as the third research variable is assessed by using a confidence rubric that covers three important dimensions. It covers present his/her ideas in natural way, communicate with others naturally, and confronting ideas.

On the first cycle, the average score of students' self-confidence was described into approximately $67 \%$. It means that most of the students were initial confidence stage in every classroom presentation and discussion to actuate their potentials. If it is classified into the three dimension of self-confidence, the first point related to presenting students' ideas in natural way, it is found that the students confidence degree is $69 \%$. Meanwhile for the dimensions of communicate with other naturally and confronting idea showed the score $66 \%$ and $65 \%$. From the above dimensions, it seemed that confronting idea became the lowest score among others elements with the score of $65 \%$. It occurred because the students did not like to confront especially the low achiever students will not confidence enough with the high achiever students. Another possible caused is because of their psychological constrain where previously in every classroom teaching the smarter students always dominate the classroom activity and they became 'classroom consultant/leader' for other students in doing assignment, and project.

Empirical data also showed that the possible cause of less confident students in confronting idea if they have different argument is their preparation before the classroom teaching is not optimum yet. Further, they tended to read with just one reference or the main source the teacher gave before so that their idea is not well developed as they only relied on one source of information only. Meanwhile for the smarter student performed better as they used to explore their idea from reading more than one sources or reference. As result, the low achiever students have higher anxiety in the classroom presentation and discussion. According to Cutrone (2009) and Subasi (2010) there are several factors stimulated the students' anxiety, namely apprehension, social evaluation, inter-learner competition and English ability.

To overcome the shortcomings on the first cycle, the researcher did several improvements on the teaching strategy toward the implementation of Round Robin discussion model on the cycle two. First, when the students present a reference has to be included in the notes. In this case, the students are not liberated in term of expressing idea, as they have to state the references they quote. Again, the reference they quote should be paraphrased as well like the previous meetings. Confrontation question in the form of debate-like concept is also prepared in the classroom teaching. Further, they are trained to debate like activity within the small group presentation before they practice among group presentation in the wider context. It is also aimed at training the students to compare and review different reference or sources they read before. The above improvement significantly affects the students' confidence. It can be seen the improvement in each dimension. First, for the dimension of present students' idea in natural way, it can be seen the significant improvement from $69 \%$ becomes $78 \%$ or it increases around $9 \%$. For the dimension of communicating naturally with others, the improvement showed significant improvement from $66 \%$ into $78 \%$. The third dimension is confronting ideas. It improved score occurs from $65 \%$ into $75 \%$. Overall improvement from the first into the second cycle is approximately $10 \%$ from $67 \%$ into $77 \%$.

\subsection{Students' Independent Learning}

Students' independent learning is determined into three main dimensions. It covers presentation with his/or her own words, doing students' worksheet/tasks independently, and executing his/her own learning style. The average score of students' independent learning in the first cycle falls into $65 \%$. It indicates that their independent learning is classified or categorised within non-dependent learning. However, it does not mean that all belongs to less independent learning as several high achiever students categorized into very independent learning. In detail, for the first dimension of independent learning doing task/worksheet independently falls into $67 \%$. Meanwhile for the second and third dimension presentation with his/or her own words falls within approximately $62 \%$ and executing his/her own learning style lays approximately within $65 \%$. The teaching activities are implemented using Round Robin discussion model. Several problems encountered in the implementation of round robin discussion method to improve students' independent learning. First, the students tended to make use of dictionary when they are encountering an unfamiliar word and asked for a translation from the teacher or their friend. Sometimes it becomes disturbance for a certain student.

Moreover, in the teaching and learning process at the end of the discussion, when they are assigning to do the worksheet individually such as in quiz, the students tended to discuss and share the answer of the worksheet and quiz with their friends. Those indications revealed that their learning style does not operate very well for low achiever students. This finding is in line with Zare (2012). He claimed that learning strategy is very influential 
toward students' English mastery. Effective learning strategies could lead into students' independent learning style.

On the cycle two, some improvements are made. First, scaffolding is implemented to assist problematic students by providing simplification or equal simplified clue for the students who have lack vocabulary problem. Reward and punishment is administered to motivate the student to do their worksheet and quiz independently. The students who have similar answer in the worksheet or quiz or test are scored very low is enough powerful to minimize cheating problem. In this occasion, the teacher also requested the students to use their own language in whole classroom activity also help minimize the cheating problem and increase confidence in answering question in both quiz and test. As result, on the second cycle there is significant increase of the students' score in term of independent learning. It improved from $65 \%$ into $93 \%$. Overall, it increases $28 \%$ from the first into the second cycle. Meanwhile for the first dimension of independent learning namely doing students' worksheet/tasks independently, it increases from $65 \%$ into $93 \%$. Next, the dimension of presentation with his/or her own words lays around $62 \%$ into $94 \%$. Finally, for the dimension of executing his/her own learning style improved from $65 \%$ into $87 \%$.

\section{Conclusion and Suggestion}

\subsection{Conclusion}

From the numerous strategies in implementing Round Robin Discussion model as one of the branches of cooperative learning can be claimed to improve students' holistic ability. It can improve students' critical thinking skill, presentation skill, confidence, and students' independent learning who enrolled TEFL course for the fourth semester students via several modifications and improvements. First, strategy multiple referencing strategies in every teaching of TEFL concept have to be implemented. It will help improve students' critical thinking skills and comprehension toward the TEFL concepts. It is proven with the increase of students' critical skills from $66 \%$ into $82 \%$. Paraphrasing strategy is implemented in every meeting and the use of students' own language in presentation and every classroom activity is a positive advantage to foster students' independent learning and confidence. It is evidenced that students' assessment score of independent learning and confidence simultaneously improved from $65 \%$ into $93 \%$ and from $66 \%$ into $77 \%$. Moreover, in fostering the students' presentation skill can be done through small group presentation and they are trained to present within the group with clear guide and roles for each student so that each student has equal practice in presentation training in the small group before they dive into the wider context. Students' presentation school also significantly improves from $65 \%$ into $85 \%$.

\subsection{Suggestion and Recommendation}

In order to foster students' holistic ability, it is suggested to the teacher to afford more practices on paraphrasing and using their own language, questioning skills, and presentation skills step by step to improve their critical thinking, independent and confidence in every discussion session. In the implementation of a round robin discussion model, a strict rules and detailed roles (such as number of question delivered and answered, time limit for each within group discussion) of each smaller group and each bigger classroom groups should be defined very clearly to minimize classroom problem and more active students' dominance in the discussion.

Finally, in the discussion activity, it is suggested to the EFL teacher assigned similar topic for each group in every discussion meeting, so that the topic will be discussed in depth and detailed. Smaller or within group presentation should be initiated first to train every student a presentation experience, skill, confidence, and independence before they dive into the bigger classroom presentation context. For further researcher, the proposition in the research finding resulted from this study could be investigated in depth so that it can contribute to the development of teaching theories in EFL/EFL settings.

\section{Reference}

Arifani, Y. (2016). The Implementation of Team-Based Discovery Learning to Improve Students' Ability in Writing Research Proposal. International Education Studies, 9(2), 111-119. https://doi.org/10.5539/ies.v9n2p111

Aydin, S., \& Zengin, B. (2008). Anxiety in Foreign Language Learning: A Review of Literature. The Journal of Language and Linguistic Studies, 4(1), 81-94.

Blanton, L. L. (1992). A Holistic Approach to College ESL: Integrating Language and Content. ELT Journal, 46(3), 285-293. https://doi.org/10.1093/elt/46.3.285

Brown, D. H. (2007). Teaching by Principles: An Interactive Approach to Language Teaching (3rd ed.). New 
York: Pearson Education, Inc.

Burns, P. C., Ross, B. P., \& Elinor, R. P. (1996). Teaching Reading in Today's Elementary School (6th ed.). Boston: Houghton Mifflin Company.

Chan, D. Y., \& Wu, G. C. (2000). A Study of Foreign Language Anxiety EFL Learners in Taiwan. Paper presented at the 2000 Educational Academic Conference, 85-100.

Cutrone, P. (2002). Overcoming Japanese EFL Learners' Fear of Speaking. Language Studies Working Papers Journal, 1, 55-63.

Delli-Carpini, M. (2006). Scaffolding and Differentiating Instruction in Mixed Ability ESL Classes Using Round Robin Activity. Internet TESL Journal, XII(3).

Gebhard, G. J. (1996). Teaching English as a Foreign Language or Second Language. Ann Arbor: The University of Michigan Press.

Harmer, J. (2001). The Practice of English Language Teaching (3rd ed.). Pearson: Longman.

Hedge, T. (2000). Teaching and Learning in the Language Classroom. Oxford: Oxford University Press.

Kemmis, S., \&. McTaggart, R. (1992). The Action Research Planner. Victoria: Deakin University.

Kusnandar. (2008). Penelitian Tindakan Kelas Sebagai Pengembangan Profesi Guru. Jakarta: Rajagrafindo Persada.

Ngaraju, C., Madhavaiah, G., \& Peter, S. (2013). Teacher Centred Learning and Students-Centred Learning in English Clasroom: the teaching Methods Realizing the Dreams of Language Learners. International Journal of Scientific Research and Reviews, 2(3), 125-131.

Subasi, G. (2010). What are the Main Sources of Turkish EFL Students' Anxiety in Oral Practice? Turkish online Journal of Qualitative Inquiry, 1(2).

Sukmadinata, N. S. (2006). Metode Penelitian Pendidikan. Bandung: PT Remaja Rosdakarya.

Zare, P. (2010). Language Learning Strategies among EFL/ESL Learners: A Review of Literature. International Journal of Humanities and Social Science, 2(5).

\section{Copyrights}

Copyright for this article is retained by the author(s), with first publication rights granted to the journal.

This is an open-access article distributed under the terms and conditions of the Creative Commons Attribution license (http://creativecommons.org/licenses/by/4.0/). 